Jurnal Widya Laksana, Vol.11, No.1, Januari 2022

\title{
PELATIHAN BAHASA INGGRIS PARIWISATA DI DESA WISATA MELER
}

\author{
Sebastianus Menggo ${ }^{1}$, Yosefina Rosdiana Su${ }^{2}$, Rizki Adiputra Taopan ${ }^{3}$ \\ ${ }^{1,2}$ Program Studi Bahasa Inggris, Universitas Katolik Indonesia Santu Paulus Ruteng \\ ${ }^{3}$ Program Studi Agronomi, Universitas Katolik Indonesia Santu Paulus Ruteng \\ e-mail: sebastian.pradana@gmail.com, josephinesu517@gmail.com, \\ rizkimicro@gamil.com
}

\begin{abstract}
Abstrak
Obyek desa wisata menawarkan aset berharga yang dapat dimanfaatkan oleh pemerintah desa dalam mempercepat kesejahteraan masyarakat desa. Pemanfaatan aset tersebut, tidak dapat dipisahkan dari kompetensi komunikasi bahasa Inggris. Kompetensi tersebut berdampak pada kualitas pelayanan wisatawan, terutama wisatawan mancan negara. Kegiatan pengabdian ini bertujuan membantu peningkatkan keterampilan berkomunikasi bahasa Inggris pariwisata dan kesadaran esensi dari hospitalitas dari para pelaku wisata desa Meler yang berjumlah 25 orang. Pengabdian dilaksanakan di rumah adat kampung Meler dan pondok wisata desa wisata Meler selama empat bulan (Maret - Juni 2021), sekali dalam sepekan. Metode yang digunakan untuk mencapai tujuan tersebut adalah ceramah, tanya jawab, diskusi, bermain peran, peragaan dan presentasi personal. Hasilnya menunjukkan bahwa, para peserta pelatihan memahami peran hospitalitas dalam pelayanan wisata dan peningkatan kelancaran berkomunikasi bahasa Inggris pariwisata.
\end{abstract}

Kata kunci: desa wisata, kompetensi bahasa Inggris, pelatihan, pengabdian

\begin{abstract}
Village tourism objects offer valuable assets that can be utilized by the village government in accelerating the welfare of the village community. Utilization of these assets cannot be separated from English communication competence. English competence has an effect on the quality of tourist services, particularly for the foreign visitors. This service activity aims to improve communication skills in the English language of tourism and awareness of the essence of hospitality towrd twenty five persons in Meler village tourism. The service was carried out at the traditional house of Meler village and Meler tourist village cottage for four months (March - June 2021), once a week. The methods used to achieve this goal are lectures, question and answer, discussion, role playing, demonstrations and personal presentation. The results show that, the training participants understand the role of hospitality in tourism services and increase the fluency of communicating English in tourism field.
\end{abstract}

Keywords: English communicative competence, tourist village, training, service 
Jurnal Widya Laksana, Vol.11, No.1, Januari 2022

\section{PENDAHULUAN}

Industri pariwisata terus

berkembang di Indonesia termasuk di wilayah Bali dan Nusa Tenggara karena tawaran berbagai potensi wisata yang belum dimanfaatkan secara optimal. Perkembangan industri pariwisata ini berkontribusi langsung terhadap pergerakan roda perekonomian masyarakat luas (Akan, Arslan, \& Isk, 2007; Sabon, Perdana, Koropit, \& Pierre, 2018).

Pariwisata di wilayah ini menawarkan prospek yang menjanjikan dengan Bali sebagai pusat pengembangannya yang didukung oleh potensi sumber daya alam dan budaya di provinsi NTB dan NTT (Menggo, 2019). Pemerintah Republik Indonesia memberikan perhatian khusus dalam memanfaatkan potensi-potensi tersebut yang ditandai oleh penetapan Kawasan Ekonomi Khusus (KEK) MandalikaNTB, Kawasan Strategis Pariwisata Nasional (KSPN) Komodo-NTT, Labuan Bajo sebagai pariwisata super premium pertama di Indonesia, dan KSPN Sanur Nusa Dua-Kuta, dan lain sebagainya (Kemenparekraf, 2015).

Keseriusan pemerintah ini tentunya harus didukung oleh sumber daya manusia yang andal dan kompeten, terutama keterampilan berkomunikasi dalam bahasa Inggris, manajemen pariwisata yang transparan, akuntabel, adil, dan berkelanjutan, serta orientasi pariwisata yang berbasis pada pelestarian ekologi dan budaya lokal (Nandi, 2008; Riadhussyah \& Subarkah, 2020).

Desa wisata merupakan salah satu potensi yang dapat dimanfaatkan oleh pemerintah desa dalam mempercepat

peningkatan

kesejahteraan masyarakat di desa wisata tersebut. Pemerintah desa terus didorong untuk menggali dan memanfaatkan berbagai potensi yang ada, dengan sejumlah pendekatan dan kebijakan yang multi dampak terhadap percepatan pertumbuhan ekonomi masyarakat desa. Pengembangan desa wisata yang multi dampak tersebut, tidak dapat dipisahkan dari kompetensi komunikasi bahasa Inggris.

Kompetensi komunikasi bahasa Inggris berperan penting dalam pengembangan desa wisata (Damayanti, 2019; Raju, Pooja, \& Rana, 2020). Kompetensi tersebut berdampak pada kualitas pelayanan, seperti memudahkan berkomunikasi antara pelaku pariwisata dengan para wisatawan yang mengujungi suatu obyek wisata, penjelasan obyek wisata kepada penutur berbahasa Inggris, dan promosi suatu obyek wisata ke seluruh dunia. Atas argumentasi ini, maka para pendamping desa wisata dan semua pemangku kepentingan memiliki suatu ekspektasi yang sama, yaitu memiliki kemampuan berkomunikasi bahasa Inggris yang mumpuni demi kelancaran dan kesuksesan pelayanan wisatawan di desa wisatanya.

Desa Meler ditetapkan sebagai desa wisata dengan Keputusan Kepala Dinas Pariwisata Kabupaten Manggarai Nomor Budpar.556/05/SK/1/2020 (Dinas Kebudayaan dan Pariwisata, 2020) yang terletak di Kecamatan Ruteng, Kabupaten Manggarai, Propinsi NTT, merupakan suatu desa yang didiami oleh masyarakat etnis Manggarai. Potensi-potensi wisata berbasis sumber daya alam, atraksi budaya, dan agro wisata yang terdapat 
di desa ini sangat menarik untuk dikunjungi dan dikembangkan. Wisatawan tidak hanya disuguhkan dengan keindahan alam lingko Meler (sawah berbentuk sarang laba-laba) tetapi juga berbagai tarian tradisi yang mengandung nilai sejarah dan edukasi, seperti tarian tiba meka (penerimaan tamu), caci (uji ketangkasan), rangkuk alu, serta keunggulan agro wisata dengan padi, cengkeh, kopi, durian, dan aneka tanaman hortikultura sebagai objek unggulannya.

Namun demikian, berdasarkan analisis situasi yang dilakukan oleh Menggo, Sutam, dan Su (2020) menunjukkan bahwa desa wisata Meler, Kecamatan Ruteng, Kabupaten Manggarai, Flores, NTT memiliki sejumlah persoalaan yang dapat menghambat kebermanfaatan semua potensi yang ada, seperti:

1. Pengelolaan desa wisata yang belum efektif dan transparan, seperti pembagian biaya dan keuntungan yang adil, belum memiliki jaringan ke ekonomi lokal dan regional, kegiatan pariwisata yang dapat melestarikan dan memperkaya tradisional dan budaya setempat;

2. Belum nampak adanya interaksi antara tamu dan masyarakat lokal dan keberlanjutan produk-produk pariwisata berbasis masyarakat;

3. Belum adanya mitra tour operator untuk membawa tamu ke desa wisata;

4. Belum tersedianya website desa wisata; dan

5. Kemampuan berkomunikasi dalam bahasa Inggris para pengelola yang sangat minim.

Hasil analisis situasi ini sebagai data awal yang perlu ditindaklanjuti dengan suatu pendampingan yang lebih kontributif sehingga berdampak terhadap peningkatan keterampilan para pengelolaan desa wisata serta kehidupan masyarakat desa secara keseluruhan (Menggo, Suastra, Budiarsa, \& Padmadewi, 2019).

Program Pengabdian kepada Masyarakat (PkM) ini dilakukan berdasarkan analsis kebutuhan di atas, yang walaupun hanya berfokus pada pelatihan bahasa Inggris pariwisata saja atas berbagai keterbatasan yang dimiliki tim PkM, Universitas Katolik Indonesia Santu Paulus Ruteng.Tim PkM terdiri atas 3 orang dosen, yaitu Dr. Sebastianus Menggo, Yosefina Rosdiana Su, M.Pd dan Rizki Adiputra Taopan, M.Si. Ketiga tutor ini dibantu oleh enam mahasiswa dari Program Studi Pendidikan Bahasa Inggris, Universitas Katolik Indonesia Santu paulus Ruteng.

Merujuk pada deskripsi di atas, maka pelatihan bahasa Inggris pariwisata di desa wisata Meler penting dilakukan.

\section{METODE}

Kegiatan pengabdian ini dilaksanakan di rumah adat kampung Meler dan pondok wisata desa wisata Meler selama empat bulan (Maret Juni 2021), setiap hari Sabtu dalam satu pekan. Peserta yang terlibat dalam kegiatan ini berjumlah 25 orang yang dibagi dalam dua kelompok. Kelompok pertama merupakan kelas orang dewasa berjumalh 10 orang yang merupakan para pendamping desa wisata. Kelompok kedua merupakan kelas anak-anak dan remaja berjumlah 15 orang. Kelas 
Jurnal Widya Laksana, Vol.11, No.1, Januari 2022

kedua ini dilayani karena kenyataan sehari-hari mereka berperan sebagai local guide dalam melayani para wisatawan, baik domestik maupun mancan Negara.

Materi dan metode dapat terapkan dalam kegiatan PkM, seperti metode ceramah, belajar bersama, dsikusi kelompok, tanya jawab, peragaan atau demonstrasi, presentasi personal,dan metode bermain peran (Aulia, Maulida, Kuzairi, \& Saputra, 2017; Menggo, Par, Gunas, \& Guna, 2021; Ndiung et al., 2020). Cuplikan contoh materi dan sejumlah metode yang dtelah digunakan dalam kegiatan PkM ini, dijelaskan pada Table 1 berikut ini.

Tabel 1. Materi dan metode dalam PkM

\begin{tabular}{|c|c|c|c|}
\hline Materi & Topik & Alokasi waktu & Metode \\
\hline I & $\begin{array}{l}\text { Greetings and self introduction: } \\
\text { a. Appropriate use of greetings } \\
\text { and expressions of welcome } \\
\text { guests } \\
\text { b. Explaining how to properly } \\
\text { greet and welcome guests } \\
\text { c. Demonstrating self } \\
\text { introduction accordingly } \\
\text { d. Practicing of other } \\
\text { introduction }\end{array}$ & 4 jam & $\begin{array}{l}\text { Bermain peran, } \\
\text { presentasi personal, dan } \\
\text { demonstrasi }\end{array}$ \\
\hline II & $\begin{array}{l}\text { Time and direction: } \\
\text { a. Asking and answering time } \\
\text { appropriately } \\
\text { b. Asking and giving and } \\
\text { direction }\end{array}$ & 4 jam & $\begin{array}{l}\text { Bermain peran dan } \\
\text { peragaan }\end{array}$ \\
\hline III & $\begin{array}{l}\text { Seasons: Differences in various } \\
\text { seasons between Indonesia } \\
\text { and other countries }\end{array}$ & 2 jam & $\begin{array}{l}\text { Ceramah, diskusi, } \\
\text { bermain peran, dan tanya } \\
\text { jawab }\end{array}$ \\
\hline IV & Hospitality on tourism service & 2 jam & $\begin{array}{l}\text { Ceramah dan tanya } \\
\text { jawab }\end{array}$ \\
\hline V & $\begin{array}{l}\text { Explaining some tourism objects: } \\
\text { a. Identifying the objects in } \\
\text { Meler tourism village } \\
\text { b. Explaining the objects in } \\
\text { Meler tourism village }\end{array}$ & 8 jam & $\begin{array}{l}\text { Ceramah, tanya jawab, } \\
\text { bermain peran, diskusi, } \\
\text { dan presentasi personal }\end{array}$ \\
\hline
\end{tabular}




\section{HASIL DAN PEMBAHASAN}

Greetings and Self Introduction

Materi dari topik ini berfokus pada bagaimana para pendamping desa wisata, remaja, dan anak-anak di desa wisata Meler dilatih untuk mampu menggunakan berbagai ekspresi greetings dengan benar dan sesuai ketika menerima tamu wisata mancan Negara. Pada kenyataan, peserta pelatihan sudah terbiasa menggunakan greetings, namun belum bisa membedakan greetings dalam situasi formal dan informal, seperti penggunaan $\mathrm{Hi}$ dan hello, responding of goodbye expression, perbedaan dari ekspresi-ekspresi how are you, how are you doing, how is everything, how's everything going, how have you been keeping, what's up, what is going on, good to see you, how's it going, nice to meet you, dan masih banyak lagi.

Materi terkait self and other introduction pada topik ini juga diberikan. Para peserta pelatihan diminta untuk memperagakan self and other introduction dengan benar dan tepat di depan para tutor dan sesama peserta belajar, seperti yang ditampilkan pada Gambar 1 berikut ini.

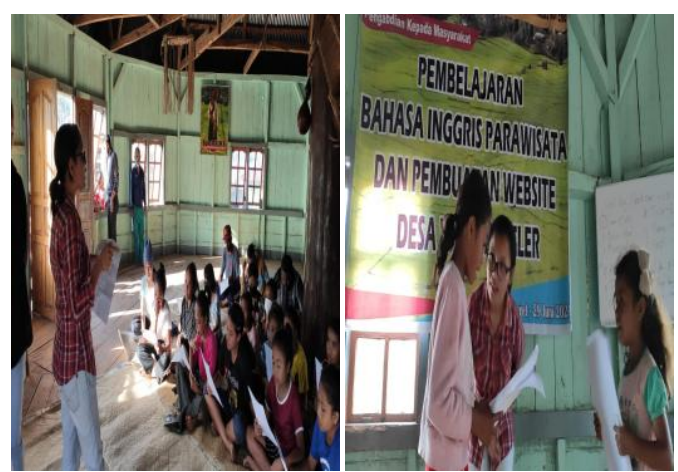

Gambar 1. Penerapan metode ceramah dan bermain peran dalam topik 1
Materi greetings and introduction penting dikuasai dalam belajar bahasa Inggris (Jibreen, 2010; Novika \& Rosaria, 2017). Mereka menegaskan bahwa greetings and introduction sebagai materi dasar yang wajib dikuasai oleh pemandu wisata karena berperan penting dalam pelayanan para tamu yang datang ke suatu obyek wisata.

Selain ekspresi-ekspresi di atas, para peserta pelatihan juga diajarkan bagaimana menyapa tamu sesuai budaya lokal Manggarai dengan mengguankan bahasa tubuh yang sesuai, seperti senyum ramah, senyum tulus, bersalaman konteks Covid-19, dan ucapan terima kasih. Perpaduan penggunaan komunikasi verbal dan non-verbal berbasis budaya lokal ini menampilkan pelayanan khas dan memberi rasa nyaman, aman, dan menyenangkan bagi para tamu (Astina \& Muliadiasa, 2016; Menggo, 2017).

\section{Time and Direction}

Topik tentang time and direction juga menarik untuk diberikan ke para peserta pelatihan. Pada dasarnya mereka sudah memahami menanyakan dan menjawab tentang jam dalam bahasa Inggris, seperti what time is?, what is it time?. Namun demikian, para peserta pelatihan mengalami kendala ketika ingin menjelaskan jam dan menit kepada para wisatawan, seperti penggunaan ekspresi leksikon o'clock (jam tepat), past (lewat), to (kurang dari), q quarter (fifteen minutes), dan a half past (thirty minutes). Para tutor memberikan teknik menjawab jam dalam bahasa Inggris untuk mengatas hambatan ini, seperti didahulukan penyebutan menit lalu diikuti oleh jamnya. 
Materi tentang direction juga masih belum dipahami oleh para peserta pelatihan. Atas masalah ini, para tutor memberikan sejumlah kosa kata dasar kunci terkait topik direction ini, seperti, roundabout (bundaran), corner (sudut), highway (jalan raya), crossroad (perempatan), bend (tikungan), Junction/intersection (persimpangan jalan), signpost (plank), turn left (belok kiri), turn right (belok kanan), go straight (jalan lurus), around the corner (di sudut), go through (melewati), go up ( jalan ke atas), go down (jalan ke bawah), dan turn back (putar balik). Kosa kata - kosa kata ini mudah dipahami oleh para peserta pelatihan ketia tutor menerapkan metode bermain peran dan peragaan dalam proses pembelajaranya.

Penerapan kedua metode ini langsung di obyek wisata. Sejumlah peserta berperan sebagai tamu yang kebingungan mencari arah ke obyek wisata, yang lainnya berperan sebagai pemandu lokal yang menjelaskan arah menuju ke obyek wisata. Metode peragaan dan bermain peran langsung berdampak pada semangat belajar bahasa Inggris siswa (Darsiana, 2018; Mustika \& Lestari, 2020; Naiborhu, 2019). Mereka menambahkan bahwa metode bermain peran tidak hanya berdampak pada aspek akademik, seperti peningkatan kemampuan bericara dan kosa kata, tetapi juga aspek psikologis siswa, seperti keberanian, kepercayaan diri siswa, dan mengurangi kecemasan siswa untuk berpraktek berbicara bahasa Inggris. Aspek psikologis ini berperan penting dalam mendukung kesuksesan belajar siswa (Bashiruddin, 2018; Menggo, Suparwa, \& Astawa, 2019).

\section{Seasons}

Materi tentang seasons ini penting diberikan kepada peserta pelatihan untuk mendukung pemahaman mereka terkait perbedaan musim di Indonesia dengan berbagai musim di negara-negara lain di dunia, sehingga mereka mampu menjelaskan kepada para tamu manca Negara, terkait waktu yang tepat untuk mengunjungi berbagai obyek wisata di desanya. Berbagai kosa kata dasar diberikan, seperti winter (musim dingin), summer (musim panas), rainy season (musim hujan), spring (musim semi), fall season (musim gugur), snow season (musim gugur), dan autumn (musim bunga). Berbagai musim ini berbeda dengan konteks Indoensia yang hanya dua musim saja. Kosa-kata dasar ini dilanjutkan dengan dialog singkat dengan metode bermain peran, seperti contoh di bawah ini.

Riski: Floren, do you like summer? (Merry, kamu suka musim panas?)

Floren : No, I dont like that, I like autumn (tidak aku tidak suka, aku suka musim bunga) and you? (dan kamu?)

Riski : I like summer because I can go to beach (aku suka musim panas karna aku dapat pergi ke pantai)

Floren : I see, I like autumn because I like flower (ooh begitu, aku suka musim bunga karna aku suka bunga)

Floren : Riski, When is the best time to visit Meler's natural beauty? (Kapan waktu terbaik untuk mengunjungi keindahan alam Meler?) 
Jurnal Widya Laksana, Vol.11, No.1, Januari 2022

Riski : Oh ... May is a great time. In May, it's another rice harvest season in Meler village (Oh..., bulan Mei waktu yang tepat. Pada bulan Mei, itu lagi musim panen padi)

Floren : Thank you very much for information (Terima kasih banyak atas informasinya)

Riski : Your welcome (sama-sama). I wait your coming in next harvest season (saya tunggu, kedatangan Anda pada musim panen nanti)

Dengan memberikan kosa-kata dasar tentang musim ini, peserta pelatihan memiliki pemahaman yang sama terkait perbedaan musim Indonesia dengan sejumlah Negara. Pemahaman ini dapat mendukung pelayanan mereka terhadap para tamu luar negeri tentang musim yang tepat mengunjungi obyek wisata (Corluka, Mikinac, \& Milenkovska, 2016; Sari, Kusumah, \& Marhanah, 2018). Mereka mengklaim bahwa, menjelaskan perbedaan musim kepada para tamu memengaruhi motivasi perencanaan pemilihan obyek wisata tamu. Oleh karena itu, season differences harus dikuasai oleh para pelaku wisata.

\section{Hospitality on Tourism Service}

Tiga tutor PkM memberikan topik ini karena hospitalitas dari para pelaku wisata di Desa wisata ini belum menunjukkan prilaku sikap hospitalitas yang memuaskan bagi para tamu yang mengunjung obyek wisata tersebut. Data ini didapat berdasarkan survei langsung lapangan oleh para tutor dan divalidasi oleh para aparatur desa dan beberapa tamu yang pernah mengunjungi obyek wisata Meler. Data menunjukkan bahwa mayoritas pelaku wisata di objek Desa wisata ini, seperti pemilik kios, warung, pemandu lokal, atraksi hiburan, penjual cendra mata, petugas pelayanan tiket dan yang lainnya belum memperlihatkan sikap ramah tamah kepada para tamu. Mereka cendrung menampilkan performansi 'sangar' yang membuat tamu tidak merasa nyaman, menghabisi waktu yang relatif singkat, dan tidak berkeinginan mengunjungi lagi obyek wisata tersebut. Selain itu, anak-anak di sekitar obyek wisata selalu ingin menemani tamu dengan meminta imbalan jasa dari para tamu.

Atas fenomena ini, para tutor memberikan penjelasan tentang hospitalitas ini, dengan berbagai contoh-contoh konkrit yang membuat para peserta pelatihan semakin sadar esensi dari faktor hospitalitas dalam mengelola suatu obyek wisata. Bahwasannya, hospitalis merupakan salah satu komponen yang wajib dijalankan oleh para pelaku wisata itu sendiri. Hospitalitas berkontribusi terhadap perbaikan manajemen suatu objek wisata (Jogaratnam, McCleary, Mena, \& Yoo, 2005; Schuckert, Liu, \& Law, 2014). Mereka menegaskan bahwa sektor pariwisata dapat berjalan dengan baik apabila didukung oleh semua faktor- faktor pendukungnya, termasuk hospitalitas. Dengan menampilkan sikap hospitalitas yang prima pada tamu maka jumlah kunjungan tamu di suatu obyek wisata akan meningkat dari waktu ke waktu. 


\section{Explaining Tourism Objects}

Peserta pelatihan dituntun untuk mampu mengidentifikasi dan menjelaskan sejumlah obyek di desa wisata Meler. Para tutor menyiapkan narasi yang pendek dalam dua bahasa (Indonesia dan Inggris) untuk setiap obyek wisata yang ada. Selanjutnya, metode bermain peran, tanya jawab, dan presentasi personal diterapkan. Wisata alam dan atraksi budaya merupakan ikon yang ada di desa wisata ini, seperti sawah berbentuk sarang laba-laba, rumah tradisional, tarian tradisional, dan dan musik tradisional. Dua contoh narasi dari sejumlah obyek yang dimaksud di tampilkan pada ilustrasi oleh gambar 2 dan 3 berikut ini.

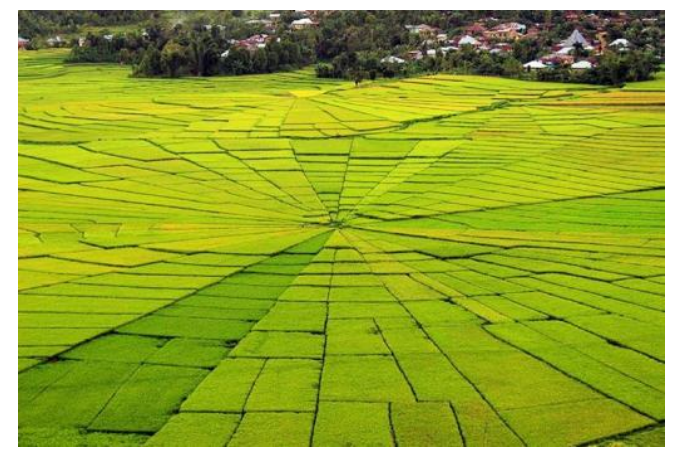

Gambar 2: Sawah berbentuk sarang labalaba

Para peserta pelatihan didorong untuk mampu menjelaskan atau menarasikan wisata alam berupa sawah berbentuk sarang laba-laba kepada wisatawan manca Negara, seperti yang ditampilkan di bawah ini.

"For the residents of Manggarai, the existence of agricultural land is incredibly important. The Manggarai people have known agriculture since the era of the nomadic hunting mode of existence until transformed to agrarianism by settling it into effect. The distribution of agricultural land in Manggarai must be based on customary laws. Generally, the distribution of land in Manggarai is adjusted to the form of the Lingko or Lodok system. As with the division of rice fields in Meler village and its surrounds. Lingko is a term for a rice field division system that starts from the midpoint. From the centre, a long line will be traced towards the outermost plane of the rice fields which is called Cicing. From the centre, a long line will be traced towards the outermost plane of the rice fields which is called Cicing. Therefore, the pattern will appear small on the inside and large on the outside. The pattern is more like a spider's web".

Ketika peserta pelatihan mampu menarasikan wisata alam di atas, dilanjutkan dengan menarasikan salah satu tarian tradisional, seperti yang ditampilkan narasi setelah Gambar 3 berikut.

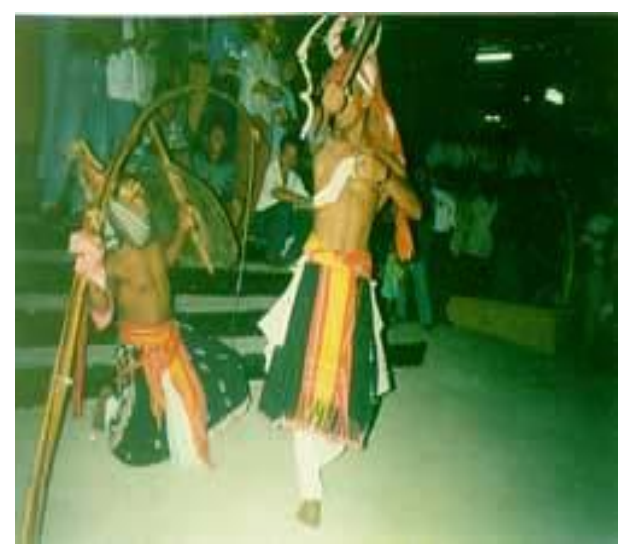

Gambar 3: tarian caci

"Caci dance is also the center and peak of dance in Manggarai culture. 
Jurnal Widya Laksana, Vol.11, No.1, Januari 2022

This dance is carried out by two men, with several pairs at once. This dance emphasizes masculinity, dexterity, sportsmanship, respect, grace, vocal arts, and courtesy to the audience and the clandestine dancers. Shield (Nggiling) is a symbol of the earth, while agang (small bamboo tied together and curved) is a symbol of the sky. The command that is the philosophy and spirituality of this dance is to hold on heaven and earth (respect God), then you will be kept away from the evil symbolized by whip (kalus). This is also an extraordinary tourism potential in Meler Village".

Sebelum melatih peserta untuk menarasikan berbgai obyek yang ada, para tutor mendampingi mereka untuk mengidentifikasi sejumlah potensi yang ada di desa wisata Meler. Identifikasi ini penting dilakukan untuk membantu peserta pelatihan memetakan skala prioritas narasi sejumlah obyek yang ada (Citra \& Sarmita, 2019).

\section{Evaluasi}

Evaluasi telah dilakukan pada kegiatan PkM ini. Evaluasi dibuat dalam bentuk lembar kuesioner dan dialogpartisipatif yang bertujuan mengetahui, respon, kekurangan dan kelemahan atas kegiatan yang telah dilakukan. Sepuluh pernyataan dalam angket evaluasi bersifat semi tertutup dengan menggunakan skala Likert (1 - 4). Namun demikian, tim PkM menyediakan lima opsi jawaban dalam angket, empat opsi bersifat tertutup, di mana peserta pelatihan disuruh untuk memilih salah satu dari empat opsi jawaban dan opsi kelima, peserta pelatihan dapat menulisnya secara langsung pada kolom yang disediakan terkait kesan mereka yang belum terkover dalam angket. Hasil evaluasi tersebut dapat disajikan pada Tabel 2 berikut ini.

Tabel 2. Hasi Evaluasi Peserta pelatihan.

\begin{tabular}{|c|c|c|c|c|c|}
\hline \multirow[t]{2}{*}{ No } & \multirow[t]{2}{*}{ Pernyataan } & \multicolumn{4}{|c|}{ Pilihan Jawaban } \\
\hline & & SS & S & TS & STS \\
\hline 1 & $\begin{array}{l}\text { Saya suka dan senang mengikuti pelatihan } \\
\text { ini }\end{array}$ & $64 \%$ & $20 \%$ & $16 \%$ & - \\
\hline 2 & $\begin{array}{l}\text { Pelatihan ini bermanfaat untk peningkatan } \\
\text { bahasa Inggris saya }\end{array}$ & $56 \%$ & $32 \%$ & $8 \%$ & $4 \%$ \\
\hline 3 & $\begin{array}{l}\text { Pelatihan ini meningkatkan bahasa Inggris } \\
\text { saya }\end{array}$ & $40 \%$ & $28 \%$ & $20 \%$ & $12 \%$ \\
\hline 4 & $\begin{array}{l}\text { Materi yang disajikan sesuai dengan } \\
\text { kebutuhan }\end{array}$ & $56 \%$ & $32 \%$ & $8 \%$ & $4 \%$ \\
\hline 5 & Isi materi jelas dan detail & $40 \%$ & $20 \%$ & $24 \%$ & $16 \%$ \\
\hline 6 & Latihan dalam modul jelas dan bermanfaat & $40 \%$ & $20 \%$ & $24 \%$ & $16 \%$ \\
\hline 7 & Tugas yang diberikan jelas & $32 \%$ & $24 \%$ & $28 \%$ & $16 \%$ \\
\hline 8 & $\begin{array}{l}\text { Alokasi waktu } 90 \text { menit setiap pelatihan } \\
\text { sudah sesuai }\end{array}$ & $44 \%$ & $36 \%$ & $20 \%$ & - \\
\hline 9 & Media dan metode dalam pelatihan menarik & $56 \%$ & $32 \%$ & $8 \%$ & $4 \%$ \\
\hline 10 & $\begin{array}{l}\text { Para turor menjelaskan materi dengan jelas } \\
\text { dan detail }\end{array}$ & $52 \%$ & $40 \%$ & $8 \%$ & - \\
\hline
\end{tabular}


Jurnal Widya Laksana, Vol.11, No.1, Januari 2022

Tabel 2 dalam pernyataan nomor 1 menunjukkan bahwa hampir semua peserta pelatihan (SS $=64 \%$ and $S=$ $20 \%$ senang dengan kegiatan pelatihan ini. Pernyataan nomor 1 ini juga tak dapat dipisahkan dari jawaban tidak setuju (16\%). Namun demikian, dominan peserta pelatihan mengatakan senang dan sukan mengikuti kegiatan ini $(S S+S=84 \%)$. Dominasi respon positif juga terjadi pada nomor 2 sampai dengan 10 (Lihat data Tabel 2 di atas). Persentasi hasil evaluasi ini bermanfaat bagi tim PkM untuk melakukan pembenahan terutama hasil pesentasi yang berada pada kategori tidak setuju dan sangat tidak setuju.

Evaluasi sebagai ruang refleksi untuk perbaikan kegiatan PkM pada tahap selanjutnya (Yuniarti \& Lingga, 2019). Konsep ini juga di perkuat oleh pernyataan dari Muryadi (2017), yang mengatakan bahwa evaluasi merupakan tahap yang tak dapat dipisahkan dari suatu kegiatan pengabdian. Widyastuti dan Es (2015) juga menegaskan bahwa evaluasi berperan penting dalam pelatihan, yaitu untuk mengetahui efektifitas atas kegiatan yang telah dilakukan. Pelatihan seyogyanya berdampak pada peningkatan kemampuan bahasa Inggris peserta pelatihan (Wanggi \& Napisah, 2020), karena materi pelatihan didesain sesuai dengan target kebutuhan peserta pelatihan yang dimaksud.

Dari pelatihan yang telah dilakukan, peserta memamahami dan mampu menggunakan berbagai ekspresi bahasa Inggris pariwisata yang mendukung pelayanan mereka.

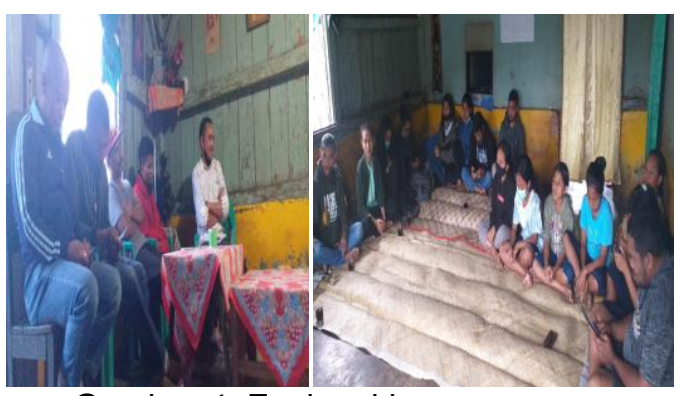

Gambar 4. Evaluasi bersama para pendamping wisata dengan tim PkM

Hasil evaluasi ini mengindikasikan bahwa pelatihan ini berdampak positif terhadap penggunaan bahasa Inggris pariwisata di desa wisata Meler. Peserta pelatihan senang dan termotivasi untuk terus berpraktek berkomunikasi dalam bahasa Inggris. Ekspresi kesenangan ini ditandi dengan kedisiplinan peserta hadir tepat waktu setiap jadwal pelatihan, foto kopi materi pelatihan, dan konsisten mengikuti pelatihan dengan mengikuti protokol Covid-19.

Kepala Dusun, yang mewakili peserta pelatihan memberi apresiasi yang tinggi dan mengharapkan kegiatan ini menjadi agenda rutin bulanan dari Universitas Katolik Indonesia Santu Paulus Ruteng sehingga kelancaran berkomunikasi dalam bahasa Inggris tetap terjaga serta tidak lunturnya performansi hospitalitas dari warga kampung Meler dalam melayani wisatawan.

\section{KESIMPULAN}

Pelatihan ini berdampak positif pada peningkatan kemampuan berkomunikasi bahasa Inggris pariwisata dan kesadaran esensi dari hospitalitas dalam pelayanan wisatawan. Topik pelatihan hanya berfokus pada greetings and 
introduction, time and direction, seasons, hospitality, identifying and explaining tourism objects. Ceramah, belajar bersama, dsikusi kelompok, tanya jawab, peragaan atau demonstrasi, presentasi personal, dan metode bermain peran merupakan sejumlah metode pembelajaran yang diterapkan oleh para tutor dalam kegiatan pengabdian kepada masyarakt ini.

\section{UCAPAN TERIMA KASIH}

Terimakasih kepada Rektor Universitas Katolik Indonesia Santu Paulus Ruteng atas dukungan finansial yang telah diberikan, Kepala Desa Meler, para pengurus desa wisata Meler, remaja, dan anak-anak sekolah SD dan SMP desa Meler, para mahasiswa Prodi Pendidikan Bahasa Inggris yang telah membantu ketiga tutor dalam melaksanakan kegiatan ini.

\section{DAFTAR PUSTAKA}

Akan, Y., Arslan, I., \& Isk, C. (2007). The impact of tourism on economic growth: The case of Turkey. Journal of Tourism, 9, 124.

Astina, M. A., \& Muliadiasa, K. (2016). Komunikasi lintas budaya antara pedagang lokal dengan wisatawan asing di pantai Sanur. Prosiding Seminar Nasional INDOCOMPAC. Hal. 696-711. Jakarta: Universitas Bakrie.

Aulia, V., Maulida, H., Kuzairi, H., \& Saputra, I. H. (2017). Pelatihan penggunaan bahasa Inggris untuk pariwisata (English for tourism) bagi siswa SMKN 4 Banjarmasin. $J$-ABDIPAMAS

(Jurnal
Pengabdian Kepada Masyarakat), 1(1), 40-49.

Bashiruddin, M. N. (2018). Factors affecting learning speaking skills in English among rural students in India. Aayushi International Interdisciplinary Research Journal 4(5),115-118.

Citra, I. P., \& Sarmita, I. M. (2019). Pemetaan potensi wisata untuk pengembangan desa wisata Muntigunung di desa Tianyar Barat. Jurnal Widya Laksana, 8(1), 85-90.

Corluka, G., Mikinac, K., \& Milenkovska, A. (2016). Classification of tourist season in costal tourism. UTMS Journal of Economics, 7(1), 71-83.

Damayanti, L. S. (2019). Peranan keterampilan berbahasa Inggris dalam industri pariwisata. Journey, 2(1), 71-82.

Darsiana, D. (2018). Upaya meningkatkan kemampuan berbicara pada mata pelajaran bahasa Inggris melalui metode demontrasi siswa kelas III SD Negeri 157 Pekanbaru. Jurnal PAJAR (Pendidikan dan Pengajaran) Program Studi Pendidikan Guru Sekolah Dasar, 2(2), 202-207.

Dinas Kebudayaan dan Pariwisata. (2020). Desa wisata. Ruteng: Dinas Kebudayaan dan Pariwisata Kabupaten Manggarai.

Jogaratnam, G., McCleary, K. W., Mena, M. M., Yoo, J. J. (2005). An Analysis of hospitality and tourism research:

Institutional 
Jurnal Widya Laksana, Vol.11, No.1, Januari 2022

contributions. Journal of Hospitality \& Tourism Research, 29(3), 356-371. https://doi.org/10.1177/109634800 5276929

Jibreen, M. K. (2010). The speech act of greeting: A theoretical reading. Journal of Kerbala University, 8(1), 1-25.

Kementerian Pariwisata dan Ekonomi Kreatif. (2015). Rencana Strategis Pengembangan Destinasi dan Industri Pariwisata Tahun 20152019. Jakarta: Deputi Bidang Pengembangan Destinasi dan Industri Pariwisata.

Menggo, S. (2017). Budaya lonto léok dalam kemampuan berbicara bahasa Inggris. The First International Conference on Language, Literature and Teaching. Hal. 722-730. ISSN 2549-5607. Surakarta: Universitas Muhammadiyah.

Menggo, S., Suastra, I. M., Budiarsa, M., dan Padmadewi, N. N. 2019. Needs Analysis of AcademicEnglish Speaking Material in Promoting 21st Century Skills. International Journal of Instruction, 12(2), 739-754. https://doi.org/10.29333/iji.2019.1 $2247 a$

Menggo, S., Suparwa, I. N., \& Astawa, I. G. (2019). Hindering factors in the achievement of English communicative competence in tourism academy students. Aksara, 31(1), 137-152. https://doi.org/10.29255/aksara.v3 1i1.235.137-152
Menggo, S. (2019). English Communicative Competence for Ecotourism Speakers. Seminar Nasional,Universitas Warmadewa Denpasar. Denpasar 30 November 2019.

Menggo, S., Sutam, I., Su, Y. S (2020). Analisis kebutuhan pengembangan desa wisata Meler (Unpublished paper). Ruteng: Universitas Katolik Indonesia Santu Paulus.

Menggo, S., Par, L., Gunas, T., \& Guna, S. (2021). Pendampingan penyusunan soal berorientasi HOTS bagi para guru SMA. Jurnal Widya Laksana,10(1),1426.

https://doi.org/10.23887/jwl.v10i1. 25010

Muryadi, A. D. (2017). Model evaluasi program dalam penelitian evaluasi. Jurnal IImiah PENJAS, 3(1), 1-16.

Mustika, N., \& Lestari, R. (2020). Metode bermain peran dalam meningkatkan kemampuan berbicara bahasa Inggris mahasiswa STIKES Perintis Padang. Edukatif: Jurnal IImu Pendidikan, 2(2), 202-209. https://doi.org/10.31004/edukatif.v 2i2.125

Naiborhu, R. (2019). Upaya meningkatkan keterampilan berbicara bahasa Inggris melalui metode bermain peran. Jurnal Global Edukasi, 3(1), 7-12.

Nandi, N. (2008). Pariwisata dan pengembangan sumberdaya 
Jurnal Widya Laksana, Vol.11, No.1, Januari 2022

manusia. Gea, Journal Pendidikan Geografi, 8(1), 33-42.

Ndiung, S., Menggo, S., Jediut, M., Sennen, E., \& Helmon, A. (2020). Pelatihan penyusunan rencana pelaksanaan pembelajaran model 1 lembar versi Menteri Nadiem bagi guru sekolah dasar. Jurnal Pengabdian Pada Masyarakat, 5(4), 963-973. https://doi.org/10.30653/002.2020 54.472

Novika, H., \& Rosaria, D. (2017). Mengajarkan self introduction dengan menggunakan metode permainan. Jurnal Al-Ikhlas, 3(1), 46-49.

Raju, S. S., Pooja, M., \& Rana, N. (2020). Role of English literature in travel, tourism and hospitality industry. Dogo Rangsang Research Journal, 10(7), 27-34.

Riadhussyah, M., \& Subarkah, A. R. (2020). Pengembangan sumber daya manusia di bidang wisata halal dalam menghadapi revolusi industri 4.0. Jurnal MSDA (Manajemen Sumber Daya Aparatur), 8(1), 1-13. https://doi.org/10.33701/jmsda.v8i 1.1164

Sabon, V. L., Perdana, M. T. P., Koropit. P, C, S., \& Pierre, W. C. D. (2018). Strategi peningkatan kinerja sektor parawisata Indonesia pada Asean Economic Community. Esensi: Jurnal Bisnis dan Manajemen, 8(2),163 -176. https://doi.org/10.15408/ess.v8i2. 5928
Sari, D., Kusumah, A. H. H., \& Marhanah, S. (2018). Analisis faktor motivasi wisatawan muda dalam mengunjungi destinasi wisata minat khusus. Journal of Indonesian Tourism, Hospitality and Recreation, 1(2), 11-22.

Schuckert, M., Liu, X., \& Law, R. (2014). Hospitality and tourism online reviews: Recent trends and future directions. Journal of Travel \& Tourism Marketing, 32, 608621. https://doi.org/10.1080/10548408. 2014.933154

Wangi, W., \& Napisah, S. (2020). Pelatihan English for young learners di "Kampoeng Batara", Kalipuro, Banyuwangi. Jurnal Widya Laksana, 9(1), 111-119.

Widyastuti, U., \& ES, D. P. (2015). Evaluasi pelatihan (training) level II berdasarkan teori the four levels Kirkpatrick. Jurnal Pendidikan Ekonomi dan Bisnis, 3(2), 119128.

https://doi.org/10.21009/JPEB.003 .2 .1

Yuniarti, D., \& Lingga, L. (2019). Pengaruh pelatihan dan pengembangan sumber daya manusia dalam meningkatkan kinerja guru pada SMK Negeri 1 Muntok. Efektor, 6(1), $98-106$. http://doi.org/10.29407/e.v6i1.127 94 